\title{
PENGARUH MOTIVASI KERJA TERHADAP KINERJA KARYAWAN DENGAN KEPUASAN KERJA SEBAGAI VARIABEL INTERVENING DI PT. INDONESIA TOURISM DEVELOPMENT CORPORATION
} (ITDC)

\author{
I Wayan Arya Lantara \\ Jurusan Pendidikan Ekonomi, Fakultas Ekonomi \\ Universitas Pendidikan Ganesha Singaraja, \\ Indonesia \\ e-mail: aryalantara@ymail.com
}

\begin{abstract}
Abstrak
Penelitian ini bertujuan untuk mengetahui (1) Pengaruh langsung antara motivasi kerja terhadap kinerja karyawan; (2) Pengaruh langsung antara kepuasan kerja terhadap kinerja karyawan; (3) Pengaruh tidak langsung kepuasan kerja antara motivasi kerja dengan kinerja karyawan. Penelitian ini dilaksanakan pada PT. Indonesia Tourism Development Corporation (ITDC), yang berlamat di Kawasan Nusa Dua, Kecamatan Kuta Selatan, Kabupaten Badung. Data dikumpulkan dengan metode wawancara, kuisioner dan dokumentasi, yang selanjutnya dianalisis dengan analisis deskriptif kuantitatif. Hasil penelitian menunjukkan bahwa (1) Ada pengaruh langsung antara motivasi kerja terhadap kepuasan kerja; (2) Ada pengaruh langsung antara kepuasan kerja terhadap kinerja karyawan; (3) Ada Pengaruh tidak langsung antara Motivasi Kerja terhadap Kinerja Karyawan melalui Kepuasan Kerja, diperoleh dari hasil penjumlahan pengaruh langsung antara Motivasi Kerja terhadap Kepuasan Kerja dan pengaruh langsung antara Kepuasan Kerja terhadap Kinerja Karyawan, Karena pengaruh langsung antara Motivasi Kerja terhadap Kepuasan Kerja dan pengaruh langsung antara Kepuasan Kerja terhadap Kinerja karyawan signifikan, maka pengaruh tidak langsung antara Motivasi Kerja terhadap Kinerja Karyawan melalui Kepuasan Kerja juga signifikan.
\end{abstract}

Kata kunci: motivasi kerja, kepuasan kerja, dan kinerja karyawan.

\section{Abstract}

This study aims to determini (1) the influence of work motivation on job satisfactition; (2) the influence of job satisfactition on emlpoyee performance; (3) indirect influence of job satisfaction between work motivation and employeeperformance. This research was conducted at PT. Indonesia Tourism Development Coorporation (ITDC) which is located in Nusa Dua, Kuta Selatan, Badung. The data ware collected by interview method, quistionnare, and documentation which then analyzed with quantitative description analysis. Result of research indicate that (1) work motivation have positive effect to job satisfaction; (2) job satisfaction have positif effect to employee's performance; (3) indirect influence between work motivation to employee performance through job satisfaction obtained from result of summation of direct inluence of work motivation to to job satisfaction and direct influence between job satisfaction on employee performance. Becouse the direct influence between work motivation on job satisfaction and direct influence of job satisfaction on employee performance is significan hance indirect influence between work motivation on employe performance through job satisfaction oldo positive.

Keywords: motivation, job satisfaction, and employee performance

\section{PENDAHULUAN}

Manajemen sumber daya manusia adalah suatu manajemen yang khusus mempelajari hubungan dan peranan manusia dalam organisasi perusahaan. Unsur manajemen sumber daya manusia adalah manusia yang merupakan tenaga kerja pada perusahaan, fokus yang 
dipelajari manajemen sumber daya manusia ini hanya masalah yang berhubungan dengan tenaga kerja manusia saja. Manusia selalu berperan aktif dan dominan dalam setiap kegiatan organisasi, karena manusia menjadi perencanaan, perilaku, dan penentu terwujudnya tujuan organisasi. Tujuan tidak mungkin terwujud tanpa peran aktif karyawan meskipun alat-alat yang dimiliki perusahaan begitu canggihnya. Alat-alat canggih yang dimiliki perusahaan tidak ada manfaatnya bagi perusahaan. Jika peran aktif karyawan tidak diikutsertakan. Mengatur karyawan adalah sulit dan kompleks, karena mereka mempunyai pikiran, perasaan status, keinginan, dan latar belakang yang heterogen yang dibawa ke dalam organisasi. Karyawan tidak dapat diatur dan dikuasai sepenuhnya seperti mengatur mesin, modal, atau gedung.

Perusahan merupakan suatu wadah yang didirikan oleh seorang atau sekelompok orang yang memiliki suatu tujuan yang sama yaitu memperoleh keuntungan. Setiap perusahaan pasti memiliki visi, misi dan tujuan yang akan dicapainya, untuk dapat mencapai tujuan tersebut perusahaan tidak lepas dari kinerja seluruh komponen yang ada di dalam perusahaan tersebut salah satunya adalah karyawan.

Dalam mencapai suatu tujuan dari perusahaan atau organisasi, seorang pemimpin harus mampu mengoptimalkan seluruh kinerja dari komponen yang bersangkutan, salah satu dari komponen itu adalah karyawan. Untuk dapat mengoptimalkan kinerja dari karyawan, seorang pemimpin harus mampu memotivasi karyawan tersebut. Faktor yang mempengaruhi kinerja adalah faktor motivasi dan faktor kepuasan. Menurut Robbins (2006), "motivasi merupakan keinginan untuk melakukan sebagai kesediaan untuk mengeluarkan tingkat upaya yang tinggi untuk tujuan-tujuan organisasi, yang dikondisikan oleh kemampuan upaya itu untuk memenuhi suatu kebutuhan individual sedangkan kinerja karyawan merupakan hasil olah pikir dan tenaga dari seorang karyawan terhadap pekerjaan yang dilakukannya, dapat berujud, dilihat, dihitung jumlahnya, akan tetapi dalam banyak hal hasil olah pikiran dan tenaga tidak dapat dihitung dan dilihat, seperti ide-ide pemecahan suatu persoalan, inovasi baru suatu produk barang atau jasa, bisa juga merupakan penemuan atas prosedur kerja yang lebih efisien".

Sedangkan dari sudut pandang kegunaan kinerja itu sendiri, Siagian (2008), "menjelaskan bahwa bagi individu penilaian kinerja berperan sebagai umpan balik tentang berbagai hal seperti kemampuan, keletihan, kekurangan dan potensinya yang pada gilirannya bermanfaat untuk menentukan tujuan, jalur, rencana dan pengembangan karirnya. Sedangkan bagi organisasi, hasil penilaian kinerja sangat penting dalam kaitannya dengan pengambilan keputusan tentang berbagai hal seperti identifikasi kebutuhan program pendidikan dan pelatihan, rekrutmen, seleksi, program pengenalan, penempatan, promosi, sistem balas jasa, serta berbagai aspek lain dalam proses manajemen sumber daya manusia". Terdapat beberapa metode dalam mengukur prestasi kerja, sebagaimana diungkapkan oleh Gomes (2003:137), yaitu.

1) Metode Tradisional merupakan metode tertua dan paling sederhana untuk menilai prestasi kerja dan diterapkan secara tidak sistematis maupun sistematis. Yang termasuk kedalam metode tradisional adalah rating scale, employee comparation, check list, free form essay, dan critical incident. (a) Rating scale merupakan metode penilaian 
yang paling tua dan banyak digunakan, dimana penilaian yang dilakukan oleh atasan atau supervisor untuk mengukur karakteristik, misalnya mengenai inisitaif, ketergantungan, kematangan, dan kontribusinya terhadap tujuan kerjanya; (b) Employee comparation merupakan metode penilaian yang dilakukan dengan cara membandingkan antara seorang pegawai dengan pegawai lainnya. Metode ini terdiri dari alternation ranking: yaitu metode penilaian dengan cara mengurutkan peringkat (ranking) pegawai dimulai dari yang terendah sampai yang tertinggi berdasarkan kemampuan yang dimilikinya, paired comparation yaitu metode penilaian dengan cara seorang pegawai dibandingkan dengan seluruh pegawai lainnya, sehingga terdapat berbagai alternatif keputusan yang akan diambil. Metode ini dapat digunakan untuk jumlah pegawai yang relatif sedikit, porced comparation (grading) metode ini sama dengan paired comparation, tetapi digunakan untuk jumlah pegawai yang relative banyak, check list yaitu metode yang hanya memberikan masukan atau informasi bagi penilaian yang dilakukan oleh bagian personalia, freeform essay dengan metode ini seorang penilai diharuskan membuat karangan yang berkenaan dengan karyawan atau pegawai yang sedang dinilainya, critical incident dengan metode ini penilai harus mencatat semua kejadian mengenai tingkah laku bawahannya sehari-hari yang kemudian dimasukan kedalam buku catatan khusus yang terdiri dari berbagai macam kategori tingkah laku bawahannya. Misalnya mengenai inisiatif, kerjasama, dan keselamatan.
2) Metode Modern merupakan perkembangan dari metode tradisional dalam menilai prestasi kerja. Yang termasuk kedalam metode modern ini adalah assessment centre. Metode ini biasanya dilakukan dengan pembentukan tim penilai khusus. Tim penilai khusus ini bisa dari luar, dari dalam, maupun kombinasi dari luar dan dari dalam. Management by objective (MBO = MBS). Dalam metode ini pegawai langsung diikutsertakan dalam perumusan dan pemutusan persoalan dengan memperhatikan kemampuan bawahan dalam menentukan sasarannya masing-masing yang ditekankan pada pencapaian sasaran perusahaan. Dalam metode Human asset accounting faktor pekerja dinilai sebagai individu modal jangka panjang sehingga sumber tenaga kerja dinilai dengan cara membandingkan terhadap variabelvariabel yang dapat mempengaruhi keberhasilan perusahaan. Berdasarkan kegunaan tersebut, maka penilaian yang baik harus dilakukan secara formal berdasarkan serangkaian kriteria yang ditetapkan secara rasional serta diterapkan secara objektif serta didokumentasikan secara sistematik. Dengan demikian, dalam melalukan penilaian atas prestasi kerja para pegawai harus terdapat interaksi positif dan kontinu antara para pejabat pimpinan dan bagian kepegawaian.

Menurut Herzbarg (Anwar: 2000) teori dua faktor tentang motivasi yaitu faktor yang membuat orang merasa puas (satisfiers) dan faktor yang membuat orang merasa tidak puas (dissatisfiers). Dalam pandangan lain, dua faktor yang dimaksudkan dalam teori motivasi Herzbarg adalah adanya dua rangkaian 
kondisi. Kondisi pertama dimana orang merasa sehat dari faktor yang memotivasi (hygiene-motivators) dan yang kedua faktor ekstrinsik dan intrinsik (extrinsicintrinsic).

Kepuasan kerja menurut Robbins (2006) "merupakan sikap umum seorang karyawan terhadap pekerjaannya". Kepuasan kerja menunjukkan adanya kesesuaian antara harapan seseorang yang timbul dengan imbalan yang disediakan pekerjaan. Kepuasan atau ketidakpuasan karyawan tergantung pada perbedaan antara apa yang diharapkan. Apabila yang didapat karyawan lebih rendah dari yang diharapkan, maka akan menyebabkan karyawan tidak puas. Faktor-faktor yang mempengaruhi kepuasan atau ketidakpuasan kerja yaitu : jenis pekerjaan, rekan kerja, tunjangan, perlakuan yang adil, keamanan kerja, peluang menyumbang gagasan, gaji, dan kesempatan berkembang.

Ukas (2006), "mengatakan bahwa hubungan Motivasi terhadap kepuasan kerja adalah dorongan yang mendapatkan usaha untuk melakukan atau memuaskan suatu kebutuhan atau tujuan disebut motivasi". Hal ini diperkuat oleh Emilia Rosyana Putri ( 2001 ) dalam penelitiannya yang berjudul pengaruh faktor-faktor motivasi terhadap kinerja karyawan. Analisis penelitian yang digunakan adalah analisis regresi berganda menggunakan program SPSS. Hasil dari penelitian adalah adanya faktor - faktor motivasi seperti gaji, lingkungan kerja, hubungan interpersonal, dan keamanan kerja berpengaruh positif terhadap kinerja karyawan. Sedangkan menurut Purnomo (2008) dalam penelitiannya mengenai kepemimpinan, motivasi kerja, dan lingkungan kerja, terhadap kinerja karyawan menunjukkan hasil yang signifikan. Dimana variabel motivasi kerja dan lingkungan yang mempunyai pengaruh yang signifikan terhadap kinerja karyawan.Karyawan merupakan pelaku yang menunjang tercapainya tujuan. Untuk mengembangkan sikap-sikap positif yang akan mengarahkan karyawan pada pencapaian tujuan perusahaan, maka motivasi harus ditingkatkan, dalam hal ini baik motivasi eksternal maupun motivasi internal. Motivasi merupakan dorongan, upaya dan keinginan yang ada pada diri manusia yang akan mengarahkan perilaku untuk melakukan tugas atau pekerjaan dengan baik, sedangkan kepuasan merupakan sikap yang menunjukkan adanya kesesuaian antara harapan dan hasil yang didapatkan.

Berdasarkan observasi awal yang peneliti lakukan, peneliti menemukan pemberian motivasi karyawan dalam melaksanakan pekerjaan sangatlah rendah. Kesempatan untuk seleksi karir dengan jenjang yang lebih tinggi masih jarang dilakukan, program reward untuk karyawan berprestasi belum terealisasikan dengan sempurna. Namun dalam beberapa hal tertentu ternyata juga masih ditemukan kondisi yang kontradiktif, yang bila diamati, juga akan dapat berpotensi menurunkan bahkan mematikan motivasi. Misalnya adanya pembedaan usia pensiun yang lebih dini bagi karyawan serta penempatan karyawan yang hanya pada posisi atau bagian yang sama dalam waktu yang relatif lama. Hal ini dapat dilihat dari kinerja karyawan yang kurang maksimal dalam melaksanakan pekerjaannya serta terdapat karyawan yang melakukan bolos kerja karena jenuh dengan pekerjaannya akibatnya perusahaan tidak dapat berjalan seperti yang sudah direncanakan. Selain itu, perhatian yang diberikan oleh atasan atau manajer terhadap karyawannya pun masih kurang.

Berdasarkan latar belakang masalah tersebut, maka penelitian ini bertujuan untuk mengetahui (1) pengaruh 
langsung antara motivasi kerja dengan kinerja karya; (2) pengaruh langsung antara kepuasan kerja dengan kinerja karyawan;(3) pengaruh tidak langsung kepuasan kerja antara motivasi kerja dengan kinerja karyawan.

\section{Hipotesis Penelitian}

Berdasarkan pada landasan teori dan kerangka pemikiran tersebut di atas, hipotesis yang diajukan dalam penelitian ini adalah sebagai berikut.

$\mathrm{H} 1$ : Motivasi kerja berpengaruh langsung terhadap kepuasan kerja.

Motivasi merupakan hasrat di dalam seseorang yang menyebabkan orang tersebut melakukan tindakan. Seseorang sering melakukan tindakan untuk suatu hal mencapai tujuan. Motivasi mempersoalkan bagaimana caranya mendorong gairah kerja bawahan, agar mereka mau bekerja keras denganmemberikan semua kemampuan dan ketrampilannya untuk mewujudkan tujuan perusahaan.

Motivasi seorang berawal dari kebutuhan, keinginan dan dorongan untuk bertindak demi tercapainya kebutuhan atau tujuan. Hal ini menandakan seberapa kuat dorongan, usaha, intensitas, dan kesediaanya untuk berkorban demi tercapainya tujuan. Dalam hal ini semakin kuat dorongan atau motivasi dan semangat akan semakin tinggi kinerjanya. H2 : Kepuasan kerja berpengaruh langsung terhadap kinerja karyawan.

Dengan diperolehnya kepuasan kerja pegawai maka kinerja pegawai akan meningkat karena pegawai merasa diperhatikan oleh perusahaan jadi ada pengaruh antara pegawai dengan perusahaan yaitu, pegawai akan terpenuhinya kepuasan kerja dan perusahaan mendapatkan kinerja yang tinggi dari para pegawainya. Hal ini sesuai dengan pendapat Robbins (2006) yang menyatakan bahwa: "kinerja merupakan tingkat efisiensi dan efektivitas serta inovasi dalam pencapaian tujuan oleh pihak manajemen dan divisi-divisi yang ada dalam organisasi. Kinerja dikatakan baik dan sukses jika tujuan yang diinginkan dapat tercapai dengan baik, kinerja juga dipandang sebagai fungsi dari interaksi antara kemampuan, motivasi, dan kesempatan, sehingga kinerja seseorang dipengaruhi oleh kepuasan kerja".

H3 : Terdapat pengaruh tidak langsung kepuasan kerja antara motivasi kerja dengan kinerja karyawan.

Menurut handoko (2002) tercapainya kepuasan pada diri seseorang akan dapat memotivasi dirinya untuk melaksanakan segala tugas yang di berikan dengan baik demi tercapainya kinerja yang maksimal. Dengan diperolehnya kepuasan kerja pegawai maka motivasi kerja pegawai akan meningkat karena pegawai merasa diperhatikan oleh perusahaan jadi ada pengaruh antara pegawai dengan perusahaan yaitu, pegawai akan terpenuhinya kepuasan kerja dan perusahaan mendapatkan kinerja yang tinggi dari para pegawainya.

Berikut merupakan kerangka pemikiran teoritis yang diambil berdasarkan hasil telaah pustaka dan penilitian terdahulu. Kerangka pemikiran teoritis yang diajukan meliputi variabel motivasi, kepuasan kerja, dan kinerja karyawan. Adapun gambar yang dapat dilihat untuk menggambarkan penelitian ini adalah sebagai berikut.

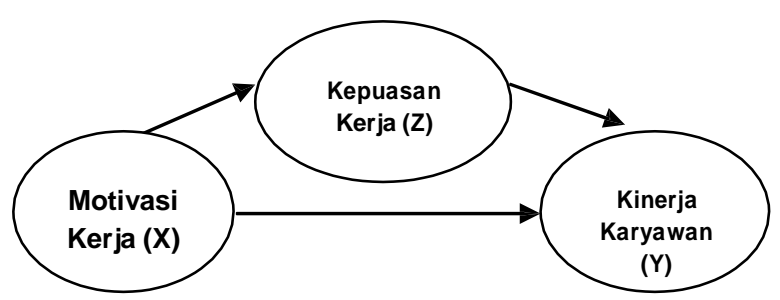

Gambar 1 Kerangka Berfikir 


\section{METODE}

Penelitian ini dilaksanakan pada PT. Indonesia Tourism Development Corporation (ITDC) dengan fokus penelitian terhadap kayawan yaitu menganalisis pengaruh motivasi kerja terhadap kinerja karyawan dengan kepuasan kerja. Variabel penelitian adalah suatu atribut atau sifat atau nilai dari orang atau objek yang mempunyai variasi antara satu dengan yang lainnya dalam kelompok itu (Sugiyono:2012). Berdasarkan telaah pustaka dan perumusan hipotesis, maka variabel-variabel dalam penelitian ini adalah.

\section{Variabel Bebas (Independen)}

Variabel bebas atau independen merupakan variabel yang mempengaruhi atau menjadi sebab timbulnya atau berubahnya variabel dependen (variable terikat). Dalam penelitian ini yang merupakan variabel bebasnya adalah motivasi kerja (Sugiyono;2012).

\section{Variabel Intervening}

Variabel intervening secara teoritis adalah variabel yang mempengaruhi hubungan dependen dan independen menjadi hubungan langsung dan tidak langsung yang dapat diamati dan diukur. Dalam penelitian ini yang merupakan variabel intervening adalah kepuasan kerja (Ghozali:2006).

\section{Variabel Terikat (Dependen)}

Menurut Sugiyono (2012) Variabel terikat atau dependen merupakan variabel yang dipengaruhi atau yang menjadi akibat karena adanya variabel bebas (independen). Dalam penelitian ini yang merupakan variabel terikatnya adalah kinerja karyawan.

Jenis data yang digunakan dalam penelitian ini adalah data kuantitatif dan kualitatif. Data kuantitatif merupakan data yang berbentuk angka-angka. Data kuantitatif dalam penelitian ini adalah pengaruh motivasi kerja terhadap kepuasan kerja, pengaruh kepuasan kerja terhadap kinerja, dan pengaruh motivasi kerja terhadap kinerja karyawan. sedangkan data kualitatif adalah data yang dinyatakan dalam bentuk kata-kata, kalimat dan gambar. Data kualitatif dalam penelitian ini adalah upaya yang dilakukan dalam memotivasi karyawan dalam meningkatkan kepuasan kerja karyawan untuk mencapai kinerja karyawan yang terbaik, serta meningkatkan motivasi kerja karyawan untuk meningkatkan kinerja karyawan. Data ini dikumpulkan berdasarkan interaksi langsung antara pengumpul data dan sumber data seperti hasil observasi, dokumentasi dan hasil wawancara.

Sumber data yang digunakan dalam penelitian ini adalah sumber data primer dan sumber data sekunder. Data primer merupakan data yang diperoleh secara langsung dari objek yang diteliti baik dari pribadi maupun dari perusahaan yang menyediakan data untuk keperluan penelitian, seperti dengan cara membaca, mempelajari, dan memahami melalui dokumen-dokumen perusahaan yang berkaitan dengan motivasi kerja, kepuasan kerja dan kinerja karyawan. Data sekunder merupakan data yang berfungsi sebagai pelengkap dengan cara melekukan wawancara secara langsung dengan pihak-pihak yang berhubungan dengan penelitian yang dilakukan.

Populasi dalam penelitian ini adalah berjumlah 180 orang. Untuk menentukan jumlah sampel dalam penelitian ini menggunakan penentuan jumlah sampel dari populasi yang di kembangkan oleh Isaac dan Michael, untuk tingkat kesalahan, $1 \%$, 5\%, dan $10 \%$. Rumus untuk menghitung ukuran sampel dari populasi yang diketahui jumlahnya adalah sebagai berikut.

$$
s=\frac{}{(\quad)}
$$

(Sugiono:2012) 
p-ISSN : 2599-1418

e-ISSN : 2599-1426

Keterangan

$\mathrm{s}$

dengan $\mathrm{dk}=1$, taraf kesalahan

bisa $1 \%, 5 \%, 10 \%$

$\mathrm{N}$

$=$ Jumlah populasi

yang diketahui

$$
\begin{array}{ll}
P=Q & =0,5 \\
D & =0,05
\end{array}
$$

Berdasarkan rumus tersebut diperoleh jumlah sampel yang digunakan sebagai berikut.

$$
\begin{aligned}
S & =\frac{(C)}{(T} \\
& =L=64,516129=65
\end{aligned}
$$

Berdasarkan perhitungan tersebut, maka jumlah sampel yang dipergunakan dalam penelitiaan ini adalah sebanyak 65 sampel.

Secara teknis penulis tidak dapat meneliti setiap anggota atau individu yang terdapat dalam perusahaan. mengingat adanya keterbatasan waktu, tenaga, biaya, serta tambahan yang berasal dari populasi tersebut, maka dilakukan terhadap sebagian dari populasi yang disebut sample. Dimana cara penarikan sampel dilakukan dengan menggunakan teknik random sampling. Untuk mengumpulkan data dalam penelitian ini maka digunakan metode sebagai berikut.

1) Penelitian Lapangan, yaitu penelitian yang dilakukan secara langsung terhadap objek penelitian. Teknik yang digunakan adalah (a) Wawancara (interview) yaitu melakukan wawancara langsung terhadap responden yang dalam hal ini adalah karyawan, hal ini dimaksudkan melalui percakapan dua arah atas inisiatif pewawancara demi memperoleh informasi dan responden; (b) Dokumentasi yaitu mendapatkan data tertulis yang dibutuhkan, yang berasal dan dokumen dan catatan-catatan
Jurnal Pendidikan Ekonomi Undiksha

Volume 10 No. 1 Tahun 2018

perusahaan seperti : jumlah karyawan, besarnya gaji dan upah yang diberikan, serta data lainnya yang dibutuhkan dalam penelitian ini; (3) Kuesioner (angket) yaitu pengumpulan data melalui daftar pertanyaan yang disiapkan masingmasing responden.

2) Penelitian Kepustakaan, yaitu penelitian yang bertujuan untuk memperoleh konsep dan landasan teori dengan mempelajari berbagai literature, buku, dan dokumen yang berkaitan dengan objek pembahasan. Untuk memperoleh data yang diperlukan di dalam penelitian ini digunakan teknik survei dengan angket. Angket adalah daftar pertanyaan yang didistribusikan melalui pos untuk diisi dan dikembalikan atau dapat juga dijawab di bawah pengawasan peneliti. Instrumen variabel penelitian diperoleh melalui jawaban responden dengan memberikan tanda pada setiap kategori pernyataan yang disusun berdasarkan skala Likert dengan 5 poin. Setiap jawaban responden akan diberi skor dan jumlah skor menunjukkan tinggi rendahnya masing-masing variabel yang diukur. Skor yang diberikan pada setiap jawaban responden adalah. Sangat Setuju (SS) dengan skor 5, setuju (S) dengan skor 4, cukup Setuju (CS) dengan skor 3, tidak Setuju (TS) dengan skor 2, sangat Tidak Setuju (STS) dengan skor 1 . Metode yang digunakan dalam penelitian ini adalah analisis jalur (path analyzing).

\section{Uji Kualitas Data}

Uji Validitas

Validitas adalah sejauh mana instrumen penelitian (angket) dalam mengungkap data yang sesuai untuk 
memecahkan masalah penelitian. Validitas juga menunjukan seberapa nyata suatu pengujian untuk mengukur apa yang seharusnya diukur, dalam hal ini yang diukur adalah butir-butir pertanyaan yang dirumuskan dalam kuesioner. Uji validitas untuk mengukur akurasi data penelitiaan melalui butir-butir pertanyaan (kuesioner) yang diajukan dalam penelitian kepada responden. Peneliti ingin mengetahui data yang ditelitivalid atau tidak valid dan diuji dengan menggunakan bantuan program SPSS dengan taraf signifikan 5\%. Langkah-langkah analisis adalah jika $r$ hitung positif dan r-hitung > r-tabel maka butir atau variabel tersebut valid. Jika $r$ hitung tidak positif dan r-hitung < r-tabel, maka butir atau variabel tersebut tidak valid, membandingkan $r$-hitung dengan $r$ tabel pada tingkat signifikan $5 \%$, membuat kesimpulan.

Uji Reliabilitas

Uji reliabilitas untuk mengukur ketepatan instrumen dengan konsistensi diantara butir-butir pertanyaan dalam suatu instrumen. Langkah-langkah analisis dengan melihat jika r-alpha positif dan $r$ alpha > r-tabel, maka butir atau variabel tersebut reliabel. Jika r-alpha tidak positif dan $r$-alpha < r-tabel, maka butir atau variabel tersebut tidak reliabel, membandingkan rule of thumb dengan $r$ alpha, membuat kesimpulan.

Uji Normalitas

Salah satu asumsi penggunaan statistik parametrik adalah asumsi multivariate normality. Uji normalitas data ini dimaksudkan untuk mengetahui normal tidaknya distribusi penelitian masingmasing variabel (Ghozali, 2011). Jika asumsi normalitas dipenuhi, maka nilai residual dari analisis juga berdistribusi normal dan independen. Normalitas dapat dilihat dari nilai critical ratio (CR) sebesar $\pm 2,58$ pada tingkat signifikansi $1 \%$. Apabila nilai $\mathrm{CR}$ yang dihasilkan dalam tabel masing-masing dimensi variabel memiliki nilai yang lebih kecil dari $\pm 2,58$ maka disimpulkan bahwa data terdistribusi secara normal.

\section{HASIL DAN PEMBAHASAN Hasil}

Hasil penelitian ini didasarkan pada pendapat responden yang merupakan karyawan dari kantor PT. ITDC. Berdasarkan sebaran usia, hampir terjadi perataan usia reponden yaitu pada usia produktif hingga usia menjelang pensiun dengan rincian sebanyak $41.5 \%$ dari total responden berusia antara 21-30 tahun, $27.7 \%$ berusia 31-40 tahun dan $23.1 \%$ berusia $41-50$ tahun. Hal ini menunjukan bahwa responden berada pada pada masa usia produktif yang merata. Dengan komposisi kelompok usia yang merata tentunya hal ini merupakan komposisi ideal dalam perusahaan karena adanya keseimbangan antar jenjang usia sehingga tercipta kondisi yang kondunsif karena tidah ada perbedaan besar dalam setiap jenjang usia produktif. Hal ini juga memungkinkan terciptanya sinergi positif antar karyawan sehingga karyawan dapat bekerja dengan maksimal baik secara individu maupun secara kelompok. Berdasarkan tingkat pendidikan, sebanyak $47.7 \%$ dari total responden berpendidikan S1, sementara sebanyak $41.5 \%$ berpendidikan SMA/SMK. Hal ini akan berkaitan dengan masa kerja. Berdasarkan masa kerja, sebanyak $27.7 \%$ responden dari total responden memiliki masa kerja di atas 15 tahun, sementara 24.6\% memiliki masa kerja 4 tahun dan antara 12-15 tahun. Ini menunjukan bahwa adanya kaitan antara tingkat pendidikan dan masa kerja dimana sebagian besar responden lulusan $\mathrm{S} 1$ memiliki masa kerja dibawah 4 tahun, sedangkan responden lulusan SMA/SMK cendrung memiliki masa kerja yang sangat lama antara 12 sampai 15 tahun keatas. Hal tersebut menunjukan meskipun tingkat 
pendidikan hanya setingkat SMA/SMK tapi tingkat pengetahuan dan kematangan tentang pekerjaan sangatlah tinggi atau sejajar dengan tingkat pendidikan S1 dikarenakan dengan masa kerja yang sangat lama tentu berimbas pula pada pengalaman kerjanyaatau dengan kata lain gap pendidikan telah ditutupi dengan pengalaman di lapangan. Dengan pola seperti ini nantinya dapat dilihat perbedaan antara para responden mengenai tingkat motivasi dan kepuasan dalam bekerja.

\section{Pembahasan}

Hipotesis 1 menyatakan bahwa motivasi kerja secara langsung berpengaruh positif terhadap kepuasan kerja. Pada tabel 4 dapat dilihat bahwa motivasi kerja memiliki nilai $t$ hitung sebesar 3.587 dengan probabilitas sebesar 0.001. Karena $t$ hitung lebih besar dari t tabel $(3.587>1.987)$ atau sig t lebih kecil dari a $(0.000<0.05)$ maka variabel motivasi kerja $(X)$ secara langsung berpengaruh signifikan positif terhadap kepuasan kerja (Z). Hasil ini sesuai dengan apa yang dikemukakan oleh Handoko (2008) dan Hasibuan (2007) yang dapat disimpulkan bahwa motivasi timbul dari tujuan seseorang untuk memenuhi kepuasannya.

Hipotesis 2 menyatakan bahwa kepuasan kerja secara langsung berpengaruh positif terhadap kinerja karyawan. Pada tabel 5 dapat dilihat bahwa kepuasan kerja memiliki nilai $t$ hitung sebesar 3.759 dengan probabilitas sebesar 0.000 . Karena t hitung lebih besar dari t tabel $(3.759>1.988)$ atau sig t lebih kecil dari $\alpha(0.000<0.05)$ maka variabel kepuasan kerja (Z) secara langsung berpengaruh signifikan positif terhadap kinerja karyawan (Y). Hasil ini sesuai dengan apa yang dikemukakan oleh Hasibuan (2007) yang menyatakan bahwa seseorang akan bekerja keras dan semakin rajin, jika mereka terus menerus mendapat pengakuan dan kepuasan dari usaha-usahanya.

Hipotesis 3 menyatakan bahwa motivasi kerja secara tidak langsung berpengaruh positif terhadap kinerja karyawan melalui kepuasan kerja. Pengaruh tidak langsung antara Motivasi Kerja $(\mathrm{X})$ terhadap Kinerja Karyawan $(\mathrm{Y})$ melalui Kepuasan Kerja (Z), diperoleh dari hasil penjumlahan pengaruh langsung antara Motivasi Kerja (X) terhadap Kepuasan Kerja $(Z)$ dan pengaruh langsung antara Kepuasan Kerja (Z) terhadap Kinerja Karyawan (Y), sehingga pengaruh tidak langsung sebesar $0.357+$ $0.331=0.688$. Karena pengaruh langsung antara Motivasi Kerja (X) terhadap Kepuasan Kerja (Z) dan pengaruh langsung antara Kepuasan Kerja (Z) terhadap Kinerja karyawan (Y) signifikan, maka pengaruh tidak langsung antara Motivasi Kerja (X) terhadap Kinerja Karyawan (Y) melalui Kepuasan Kerja (Z) juga signifikan positif.

\section{SIMPULAN DAN SARAN Simpulan}

Dalam penelitian ini dapat di simpulkan sebagai berikut; (1)Motivasi kerja secara langsung berpengaruh positif terhadap kepuasan kerja; . (2) Kepuasan kerja secara langsung berpengaruh positif terhadap kinerja karyawan; (3) Pengaruh tidak langsung antara Motivasi Kerja terhadap Kinerja Karyawan melalui Kepuasan Kerja, diperoleh dari hasil penjumlahan pengaruh langsung antara Motivasi Kerja terhadap Kepuasan Kerja dan pengaruh langsung antara Kepuasan Kerja terhadap Kinerja Karyawan, Karena pengaruh langsung antara Motivasi Kerja terhadap Kepuasan Kerja dan pengaruh langsung antara Kepuasan Kerja terhadap Kinerja karyawan signifikan, maka pengaruh tidak langsung antara Motivasi Kerja terhadap Kinerja 
p-ISSN : 2599-1418

e-ISSN : 2599-1426

Karyawan melalui Kepuasan Kerja juga signifikan positif.

\section{Saran}

Berdasarkan hasil analisis data kuesioner, perusahaan perlu sedikit memperhatikan tingkat kepuasan kerja karyawan terutama dalam hal gaji, promosi, dan pengawasan karena motivasi kerja berpengaruh secara tidak langsung terhadap kinerja karyawan melalui kepuasan kerja. Perlu diberikan pemahaman dan apresiasi secara nyata terhadap kepuasan kerja karyawan khususnya gaji, promosi, dan pengawasan dengan indikator masing-masing seperti penerimaan upah yang sudah sesuai dengan standar upah yang berlaku, pengembangan karir dengan kesempatan memperoleh promosi, serta kesempatan berpartisipasi dan terlibat dalam pengambilan keputusan yang berkaitan dengan pekerjaan.

Apabila ingin melakukan penelitian lebih lanjut mengenai topi ini ditempat yang sama, sebaiknya dilakukan pada tahun yang berbeda agar data yang dianalisis lebih lengkap sehingga hasil yang didapatkan lebih akurat karena objek yang dilihat adalah manusia yang tidak dapat dilihat perubahan perilakunya dalam waktu singkat.

\section{DAFTAR PUSTAKA}

Dessler, Gary. 2009. Manajemen SDM buku 1. Jakarta: Indeks.

Gibson, dkk. 1997. MANAJEMEN Edisi Kesembilan Jilid 1. Jakarta: Erlangga.

Ghonzali. 2009. EKONOMETRIKS. Semarang: Undip.

Ghozali, Imam. 2011. Aplikasi Analisis Multivariate Dengan Program SPSS. Semarang: BP Universitas Diponegoro Gomes, Faustino Cardoso. 2003. MSDM. Yogyakarta: Andi.
Jurnal Pendidikan Ekonomi Undiksha

Volume 10 No. 1 Tahun 2018

Griffin, Ricky W. 2003. Manajemen Jilid 2. Jakarta: Erlangga.

Handoko T. Hani. 2002. Manajemen, Edisi Kedua, Cetakan Ketigabelas. Yogyakarta: BPFE.

Hasibuan, H. Malayu. 2001. Manajemen Sumber Daya Manusia, edisi revisi, cetakan ketiga. Jakarta: Bumi Aksara.APU.

Prabu Mangkunegara, Anwar. 2000. Manajemen Sumber Daya Manusia. PT. Remaja Rosda Karya.

Robbins, Stephen. P. 2006. Perilaku Organisasi (alih bahasa Drs. Benjamin Molan), Edisi Bahasa Indonesia. Klaten: PT. Intan Sejati.

Siagian, Sondang. 2002. Manajemen SDM. Jakarta : Bumi Aksara.

Sugiyono. 2012. Metode Penelitian Kuantitatif Kualitatif dan R\&D. Bandung: CV. Alfabeta.

Simamora, Henry, 2004, Manajemen Sumber Daya Manusia, cetakan pertama edisi ke tiga. Yogyakarta: YKPN. 